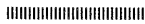

\title{
ゾル・ゲル法によって作製した $\mathrm{PbTiO}_{3}-\mathrm{MgTiO}_{3}$
} 準安定固溶体の誘電的性質

\author{
吉岡 秀 樹 \\ （兵庫県立工業技術センタ一，654 神戸市須磨区行平町 3-1-12)
}

\section{Dielectric Properties of $\mathrm{PbTiO}_{3}-\mathrm{MgTiO}_{3}$ Metastable Solid Solutions Prepared by the Sol-Gel Method}

\author{
Hideki YOSHIOKA
}

(Hyogo Prefectural Institute of Industrial Research, 3-1-12, Yukihira-cho, Suma-ku, Kobe-shi

654)

$(1-x) \mathrm{PbTiO}_{3}-x \mathrm{MgTiO}_{3}$ metastable solid solutions with $x$ up to 0.5 were prepared by heating alkoxy-derived gels at $773 \mathrm{~K}$ for 24h. X-ray diffraction analysis reveals that the perovskite solid solutions were obtained as a tetragonal structure when $x<0.2$, and as a cubic structure when $0.2 \leqq x \leqq 0.5$. Dielectric measurements for the pressed powders show that no dielectric peak due to a ferroelectric phase transition was observed for the solid solutions. Both dielectric constants and dielectric losses decreased with increasing $\mathrm{Mg}$ content.

[Received March 16, 1990; Accepted July 16, 1990]

Key-words : $\mathrm{PbTiO}_{3}, \mathrm{MgTiO}_{3}$, Solid solution, Perouskite oxides, Sol-gel, Dielectric properties, Ferroelectric transition

\section{1. 緒 言}

$\mathrm{PbTiO}_{3}$ はペロブスカイト型構造をもつ代表的な強誘 電体である。 $\mathrm{PbTiO}_{3}$ をベースとする固溶体も実用的に 重要で，数多くの系が研究されている。それらの研究の 結果， $\mathrm{PbTiO}_{3}$ には種々の元素が置換固溶するが，その 中でマグネシウムイオンは少量しか固溶しないことが報 告されているㄹ. おそらく $\mathrm{Mg}^{2+}$ のイオン半径がペロブ スカイト型構造の A サイトを置換するには小さく,一方, $\mathrm{B}$ サイトを置換すると電荷のバランスをとるために多 量の格子欠陉を生成する必要があるため上考えられる。

本研究ではチタンアルコキシドを用いたゾル・ゲル法 によってペロブスカイト型構造を示す, $\mathrm{PbTiO}_{3}$ $\mathrm{MgTiO}_{3}$ 準安定固溶体（以下PMT 固溶体とする）の作 製を試みた。得られた試料の密度測定からその久陥構造 を考察した。また，固溶体の形成による誘電的性質の変 化についても検討した。

\section{2. 実験方法}

表 1 に示したように, 作製した固溶体の組成は $(1-x)$ $\mathrm{PbTiO}_{3}-x \mathrm{MgTiO}_{3}$ として $x=0$ 〜 0.5 である。テトライ ソプロポキシチタン (TIP) のエタノ一ル溶液に所定量 のトリエタノールアミン (TEA), 酢酸鉛三水和物 $(\mathrm{Pb}$ $\left.(\mathrm{OAc})_{2}\right)$ ，酢酸マグネシウム四水和物 $\left(\mathrm{Mg}(\mathrm{OAc})_{2}\right)$ を 溶解した。これをエ夕ノール-水混合溶液で加水分解し，
ゾル溶液とした。ゾルを静置すると数時間から数日後に ゲル化した。得られた湿潤ゲルを $333 \mathrm{~K} て ゙$ 乾燥後, $773 \mathrm{~K}$ で 24 時間熱処理して，粉末試料を作製した。

試料の結晶相は $\mathrm{Cu} K \alpha$ 線を用いた粉末 X 線回折法 (XRD) で検討した。格子定数は，Si を内部標準とし， (100) (101)（111）（200）の回折線から最小二乗法によっ て算出した。試料の密度は, ヘキサクロロ-1,3-ブダジ エンを溶媒とし，ピクノメータによって測定した。誘電 的性質の測定は，粉末を $150 \mathrm{MPa}$ で直径約 $10 \mathrm{~mm}$ ，厚 さ $0.5 \sim 0.8 \mathrm{~mm}$ の円板状に成形し，スパッ夕一蒸着で 両面に Pt-Pd 電極を形成した試料について行った。測 定器は YHP-4275 A 型 LCR メータ一，二端子法，測定 周波数 $1 \mathrm{MHz}$, 測定電圧 $0.05 \mathrm{~V}$ で，室温から $800 \mathrm{~K}$ 付 近までを $2 \mathrm{~K} / \mathrm{min}$ で昇温させながら, 誘電率 $\left(\varepsilon^{\prime}\right)$ と

Table 1. Compositions (Molar ratio) studied.

\begin{tabular}{lllll}
\hline $\mathrm{Pb}(\mathrm{OAC})_{2}$ & $\mathrm{Mg}(\mathrm{OAC})_{2}$ & TIP & TEA & $\mathrm{H}_{2} \mathrm{O}$ \\
\hline 1.00 & 0.00 & 1.00 & 0.50 & 17 \\
0.98 & 0.02 & 1.00 & 0.50 & 24 \\
0.95 & 0.05 & 1.00 & 0.50 & 28 \\
0.90 & 0.10 & 1.00 & 0.50 & 30 \\
0.80 & 0.20 & 1.00 & 0.50 & 32 \\
0.67 & 0.33 & 1.00 & 0.50 & 32 \\
0.50 & 0.50 & 1.00 & 0.40 & 20 \\
\hline
\end{tabular}




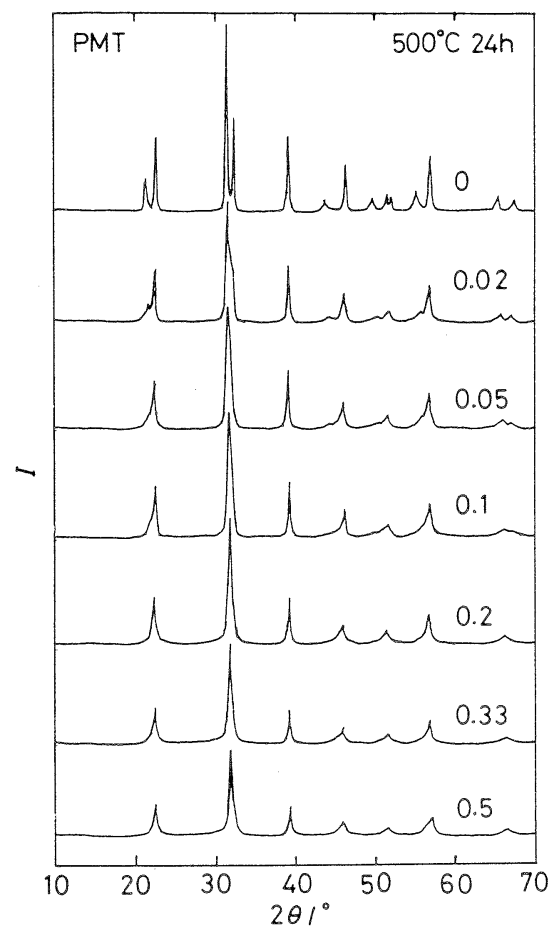

Fig. 1. XRD patterns of samples heated at $773 \mathrm{~K}$ for $24 \mathrm{~h}$.

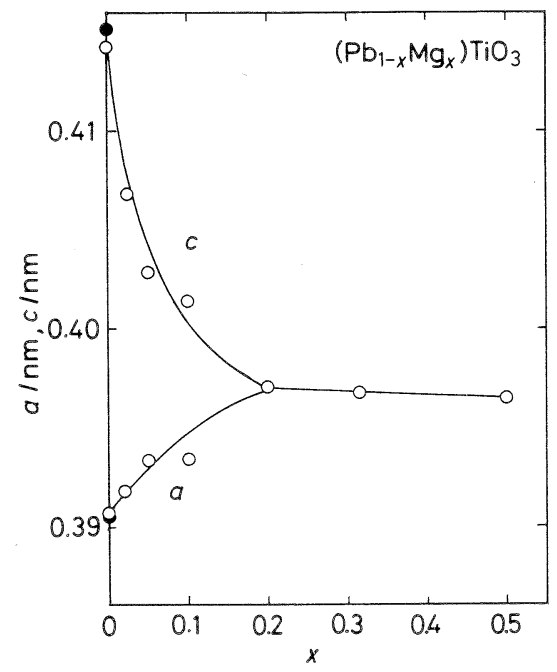

Fig. 2. Lattice parameters of gel-derived $\mathrm{PbTiO}_{3}-$ $\mathrm{MgTiO}_{3}$ solid solutions.

誘電損失 $(\tan \delta)$ を測定した。誘電率の密度による補 正は行わなかった。

\section{3. 結果}

いずれの組成の試料もゲル状態ではアモルファス状の $\mathrm{X}$ 線回折図形を示した。 $500^{\circ} \mathrm{C}$ での熱処理によってゲル は結晶化し， $x=0.5$ までの組成で図 1 に示すようにペ ロブスカイト型の回折図形が得られた。 $x$ の増加に伴っ

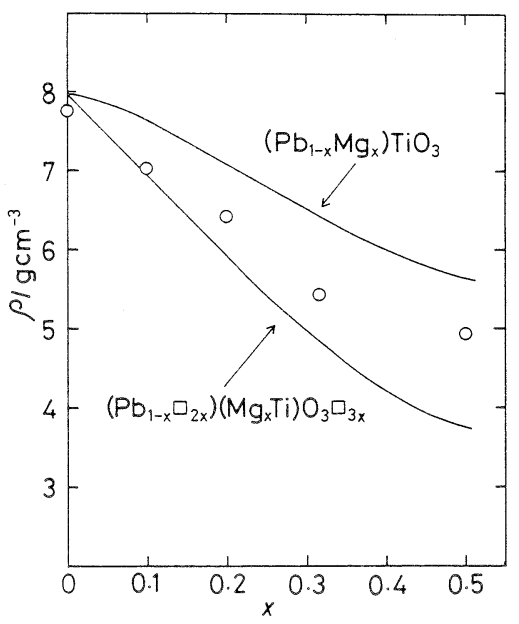

Fig. 3. Measured densities of gel-derived $\mathrm{PbTiO}_{3}-$ $\mathrm{MgTiO}_{3}$ solid solutions and calculated lines based on the defect models.

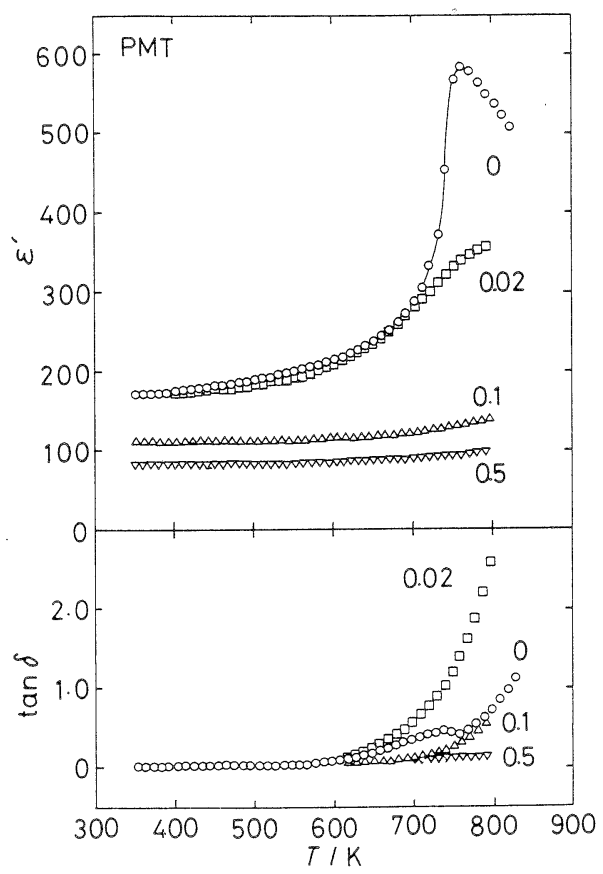

Fig. 4. Dielectric constants and dielectric losses of gel-derived $\mathrm{PbTiO}_{3}-\mathrm{MgTiO}_{3}$ solid solutions as a function of temperature.

て正方晶から立方晶へと変化していることがわかる。ま た, 他の結晶相はX線回折では観測されなかった。なお, $\mathrm{Mg}$ 量を更に $x=0.67$ まで増加させると, $500^{\circ} \mathrm{C}$ の熱処 理で立方晶ペロブスカイト相とアモルファス相の二相, $550^{\circ} \mathrm{C}$ では正方晶ペロブスカイト相とイルメナイト型 $\mathrm{MgTiO}_{3}$ 相が生成し, ペロブスカイト型の単一相は得ら れなかった。

図 2 に格子定数の組成による変化を示す. $x=0$ にお 
ける格子定数は $a=0.3912 \mathrm{~nm}, \quad c=0.4149 \mathrm{~nm}$ で $\mathrm{PbTiO}_{3}$ 単結晶に対する文献值 ${ }^{2)}(a=0.3904 \mathrm{~nm}, c=$ $0.4152 \mathrm{~nm})$ とほぼ一致した. $x$ の増加とともに $a$ 軸方 向の格子定数は増加し, $c$ 軸方向では減少した. しかし, この領域で格子定数は $\mathrm{Mg}$ の含有量に対し直線的には 変化していない. $x=0.2$ 付近で結晶系は立方晶へと変 化し, $\mathrm{Mg}$ の含有量が増加すると格子定数は少しではあ るが小さくなった。

図 3 に密度の測定結果を示す。実線は後述する欠陷構 造モデルに対する計算曲線である。 $\mathrm{Mg}$ 含有量の増加と ともに，固溶体の密度は減少することがわかる.

図 4 には誘電率と誘電損失の測定結果を示す. $x=0$ では誘電率の極大が $763 \mathrm{~K}$ に存在し, 誘電損失にもピー クが見られた。これは, $\mathrm{PbTiO}_{3}$ の正方晶一立方晶相転 移 (強誘電体一常誘電体転移) によるものである ${ }^{3)} \cdot x=$ 0.02 では, $700 \mathrm{~K}$ 以下で $\mathrm{PbTiO}_{3}$ と同程度の誘電率を示 したが，700K以上では異なり明確なピークは見られな かった，また，誘電損失は大きく，高温で単調に増加す る曲線であった． $x=0.1,0.5$ と $\mathrm{Mg}$ の含有量が増す とともに, 誘電率は低くなった。また, 広い温度範囲で 一定值を示し，高温でわずかに上昇するたけけであった。 誘電損失も高温まで低い値を維持した。

\section{4. 考察}

図 1 のX 線回折の結果では, 熱処理後の試料は $x<$ 0.5 までペロブスカイト型の単一相であった. また, 図 2 に示すように格子定数が組成によって変化することか ら，固溶体を形成していることが考えられる。しかし， X 線回折法では第二相が存在しても，結晶性が悪けれ ば観測されない。このため，X 線回折の結果からでは ペロブスカイト相への $\mathrm{Mg}$ の固溶量を確定することは できなかった。

PMT 固溶体が ( 1 ) 式に示すような $\mathrm{Pb}^{2+} と \mathrm{Mg}^{2+}$ の 単純な置換固溶によって形成されているならば，格子定 数は $\mathrm{Mg}$ 含有量に対して直線的に変化することが予想 される。

$$
\begin{aligned}
& (1-x) \mathrm{PbTiO}_{3}+x \mathrm{MgTiO}_{3} \\
& =\left(\mathrm{Pb}_{1-x} \mathrm{Mg}_{x}\right) \mathrm{TiO}_{3}
\end{aligned}
$$

しかし，図 2 に示すように，格子定数は $\mathrm{Mg}$ 含有量の 小さいところで大きく変化した後, 次第に緩やかになり, 立方晶に変化した後, $x>0.2$ では直線的にわずかずつ 小さくなっている。この格子定数の変化に対して, 次の 二つの理由が考えられる. (a) X線回折では観測できな い第二相が存在し，それによって主相中の $\mathrm{Mg}$ 固溶量 が試料全体の Mg 含有量とは異なる, (b) PMT 固溶体 の構造が（1）式に示すような単純な置換固溶型ではな い。（a）については第二相の確認と固溶量の決定が容易 ではない。（b）については図 3 に示す密度データから
考察できるが，低温処理によって作製した微粒子の密度 測定は実験上難しく，明確には決定できない。ここでは 第二相が存在しないと仮定した場合のPMT 固溶体の 欠陥構造について, 密度データから推察できるひとつの モデルを提案するにとよ゙める.

$\mathrm{PbTiO}_{3}$ への $\mathrm{Mg}^{2+}$ の固溶には, (1) 式に示したAサ イト置換以外に, (2) 式に示す Bサイト置換, 及び $\mathrm{Mg}^{2+}$ の格子間への侵入型固溶が考えられる.

$$
\begin{aligned}
& (1-x) \mathrm{PbTiO}_{3}+x \mathrm{MgTiO}_{3} \\
& =\left(\mathrm{Pb}_{1-x} \square^{\mathrm{c}}{ }_{2 x}\right)\left(\mathrm{Mg}_{x} \mathrm{Ti}\right) \mathrm{O}_{3} \square^{\mathrm{a}}{ }_{3 x}
\end{aligned}
$$

ここで $\square^{\mathrm{c}}$ は陽イオン空孔， $\square^{\mathrm{a}}$ は陰イオン空孔を表す。 図 3 には密度の測定結果と同時に，（1）式及び（2） 式から求めた計算曲線を示した. なお, 侵入型固溶の場 合の密度の計算值は（1）式と同じになる。図 3 の結果 からは， $x \leqq 0.1$ では密度は $(2)$ 式に従っており, $\mathrm{Mg}^{2+}$ は主としてBサイトに置換するとともに, 置換量 の 2 倍の陽イオン空孔 (A サイト空孔) と 3 倍の酸素 空孔を生成する。 $x$ が増加すると空孔の数も増加し, A サイトの空孔は $x=0.1$ で $18 \%, x=0.5$ では $67 \%$ に達 することになる。そこで $x>0.1$ では $\mathrm{Mg}^{2+}$ は格子間あ るいは多量の空孔が生じた Aサイトにも固溶しはじめ, 密度の測定值は $(1)$ 式に近づくと考えられる.

このように陽イオンサイト，陰イオンサイトともに多 量の格子空孔をもつ固溶体の生成については従来報告が ない. また，先に述べたように低温処理によって作製し た微粒子の密度測定は難しく, 欠陥構造を密度のデー夕 のみから決定することは不可能である.このため, 久陥 構造の直接的な観察, 第二相の有無の確認と固溶量の決 定が必要である。なお, 本研究で得られたPMT 固溶 体は高温では不安定で，例えば $x=0.33$ の固溶体を 973 $\mathrm{K}$ で熱処理すると正方晶 $\mathrm{PbTiO}_{3}$ とイルメナイト型 $\mathrm{MgTiO}_{3}$ の二相に分解してしまう。このため, 常圧での 熱処理では焼結体を作製することは不可能である.

誘電的性質は $\mathrm{Mg}$ の添加によって著しく変化するこ とが示された。図 4 は焼結体ではなく粉末成形体につい ての測定結果であるため, 絶対値についての詳細な議論 はできないが，（1）わずか $x=0.02$ で，相転移に起因 する誘電率のピークが見られなくなること，（2） $\mathrm{Mg}$ 含有量が更に増加すると誘電率と誘電損失はともに低下 することがわかる。粉末成形体では粒子の表面状態や微 量の第二相によって誘電率の測定結果も影響を受け，そ れによって誘電率ピークが消滅することも考えられる.

しかし， $x=0.02$ ではペロブスカイト相の格子定数自体 が著しく変化しており, また示差走査熱量測定 (DSC) によっても，転移による熱量ピークが消滅していたこと から, 誘電率ピークの消滅は表面析出相の影響ではなく $\mathrm{Mg}$ のペロブスカイト相への固溶によると考えられる.

$\mathrm{PbTiO}_{3}$ や $\mathrm{BaTiO}_{3}$ の強誘電体転移に基づく誘電率の 
ピークが, 固溶体の形成によって変化することは数多く の研究で明らかにされている. なかでも, $\mathrm{Ca}^{2+}$ を固溶 した $\mathrm{BaTiO}_{3}$ については, その久陷構造や誘電特性の組 成による変化が議論されている. 坂部は, 過剩に添加さ れた $\mathrm{Ca}^{2+}$ は Bサイトに固溶するとともに酸素空孔を生 成することを示しだ). Zhuang らは $\mathrm{Ca}^{2+}$ が $\mathrm{B}$ サイトに $5 \%$ 固溶した場合, $\mathrm{Ca}^{2+}$ と $\mathrm{Ti}^{4+}$ とのイオン半径の差に 起因する格子歪によって, $\mathrm{BaTiO}_{3}$ の誘電率ピークは散 漫になり,キュリ一点は室温付近まで低下したと報告し ている5). PMT 固溶体では, $\mathrm{Mg}^{2+}$ と $\mathrm{Ti}^{4+}$ とのイオン半 径の差は小さいため, 誘電率のピークの著しい変化をイ オン半径の差による格子丕で説明することはできない. また, X 線回折の結果から, $x<0.2$ の固溶体は室温で 正方晶のペロブスカイト型構造であり, 加熱によってこ れらは立方晶へ転移しているはずである。しかし， $x=$ 0.02 の試料でも誘電率のピークは観測されない。この 理由は相転移が極めて広い温度範囲にわたって起こるた めと考えられる。

\section{5. 結 論}

ゾル・ゲル法によって $\mathrm{PbTiO}_{3}-\mathrm{MgTiO}_{3}$ 準安定固溶
体の作製を試みた．X線回折では， $x<0.5$ までペロブ スカイト型の結晶相が得られた。格子定数は $\mathrm{Mg}$ 含有 量によって変化したが, その変化は含有量に対して直線 的ではなかった，これは，X線回折では観測できない 第二相によって固溶量が置換量とは異なっているか, あ るいは多量の格子欠陥が生成したためと考えられる。 $\mathrm{PbTiO}_{3}$ の正方晶一立方晶間相転移による誘電率のピー クは，固溶体の形成によって見られなくなった。 $\mathrm{Mg}$ 固 溶量の増加により, 誘電率, 誘電損失はともに低下した。

謝辞 本研究に当たり, 有用な助言を頂いた大阪大学産 業科学研究所・金丸文一教授, 兵庫県立工業技術センター・橋 詰源蔵参事ならびに元山宗之無機材料部長に感謝の意を表しま す.

\section{文献}

1) 小舟正文, 坂本千秋, 藤井 知, 杉江他曽宏, セラミッ ク又論文誌, 96, 935-41 (1988).

2) G. Shirane and S. Hoshino, J. Phys. Soc. Jpn., 6, 265-70 (1951).

3) J.P. Remeika and A. M. Glass, Mater. Res. Bull., 5, 37-46 (1970).

4）坂部行雄，七ラミックス，22,866 (1987).

5) Z. Q. Zhuang, M. P. Harmer, D. M. Smyth and R.E. Newnham, Mater. Res. Bull., 22, 1329 (1987). 